\title{
Anthropological Aspects of Józef Tischner's Philosophy of Drama
}

\author{
Bogdan Trocha \\ Doctor of Science (Philology), Professor, University of Zielona Góra \\ (Zielona Góra, Poland) \\ E-mail: bwtrocha@gmail.com \\ https://orcid.org/0000-0003-2348-4813
}

The main aim is to show the evolution of philosophical thoughts and searches of Józef Tischner. He is one of the most important contemporary philosophers in Poland. As a priest and student of Roman Ingarden, he combined phenomenology with the Catholic model of a man in his philosophical work. The specificity of Tischner's philosophical output needs to be discussed separately because of its polemical character in relation to Thomism and Marxism, as well as the great influence of philosophical essays in which Tischner commented on the condition of society in the times of popular democracy and indicated alternative solutions to Marxism, setting philosophical foundations for a public discussion on the ethics of solidarity, the role of encounter and morality in everyday life, and also indicating the great importance of hope. The article discusses one of the most important problems that Tischner addressed in the context of his studies on Heidegger and Lévinas, creating a unique concept of a man inscribed in the philosophy of drama. This Tischner's theory has many pragmatic features among many of its audience, which are supposed to lead, above all, to a proper understanding of the phenomenon of the meeting.

Most of the studies devoted to Tischner's philosophy focus on its relationship with religious tradition, phenomenological tradition or the political perspective of his philosophical essays. In this case, the subject of analysis was made the Philosophy of drama, pointing not only to its sources, which are not always explicitly present in Tischner's text itself but above all to the discursive dimension of this philosophical proposal. The results of this article not only allow a better understanding of the mechanisms present in Polish Christian philosophy but above all point to the possibility of using philosophical reflection in borderline situations. Thus, the presentation of Tischner's philosophical concepts concerning the issues of dialogue and drama makes it possible to introduce mechanisms described by their creator into the field of independent cognitive projects concerning dialogue space, undertaken by readers.

Keywords: axiology; philosophy of dialogue; anthropology; philosophy of drama

Received: February 2, 2019; accepted: March 6, 2018

Future Human Image, Volume 11, 2019: 104-112.

https://doi.org/10.29202/fhi/11/12

Józef Tischner was born on 12 March 1931 in Stary Sącz in a teaching family, died in Cracow on 28 June 2000. He spent his childhood in Łopuszna, graduated from high school in Nowy Targ, after graduation he studied law for a year at the Jagiellonian University and then

(C) Trocha, Bogdan, 2019 
entered the seminary. As a priest, he began his studies in Warsaw at the Faculty of Philosophy and Theology of the Academy of Catholic Theology, and from 1957 he studied at the Faculty of Philosophy and History, where he participated in a doctoral seminary run by Professor Roman Ingarden, a pupil and collaborator of Edmund Husserl. Tischner met there the most important students of Ingarden, such as Adam Węgrzecki, Maria Gołaszewska, Władysław Stróżewski, who in later years will co-create the phenomenological philosophical environment in Kraków. The work under Roman Ingarden resulted in profound studies of the views of Edmund Husserl, Max Scheler, Martin Heidegger, Heinrich Rickert and Ingarden himself. In 1963, Tischner defended his doctoral dissertation The Transcendent Self in the Philosophy of Edmund Husserl [Tischner, 2006]. Already in this book, it is clear that Tischner will be looking for his own way of showing off in contemporary human philosophy. He had the ability to ask insightful philosophical questions, discovering the essential character of the analysed contents, which in his case was always in line with his religious formation. In his doctoral dissertation, we can already see an element of critical reflection in relation to the Husserl concept of the transcendental self as a basis for building a philosophical description of the human condition.

The meeting with Ingarden resulted not only in an understanding of the phenomenological method and the diagnosis presented by its leading representatives but also at the beginning of his own philosophical path, as can already be seen during his stay in Leuven. There he worked not only on the materials collected in the surviving Husserl Archive but also on philosophers who, while remaining in the area of phenomenological thought, began to practice their own philosophy. This is the case of Emmanuel Levinas, whose philosophy meets in Leuven and which will have a great influence on the shaping of the views of the Krakow philosopher, particularly important will be Levinas's later works written after 1950, in which he will take up concepts of Franz Rosenzweig's philosophy of dialogue in order to construct his own concept of man inscribed in the tension between existence and being and in relations with the Other. It is extremely important that the philosophy of dialogue is a philosophy that uses biblical figures and gives them new philosophical meanings. The first study of Levinas' writings was also accompanied by the study of Paul Ricoeur's hermeneutics. What is extremely important, both philosophers remained immersed in the space of religious thinking, which was looking for its scientific perspective. It is in Louven that Tischner, for the first time, faces problems that "give rise to thinking" and with great difficulty succumb to the rigors of philosophical method. His research is increasingly connected with the source description of the nature of the human condition. At the same time, Tischner pays great attention to the decisions and reflections of the most important philosophers of his time, who raised issues that interfere with him. This also seems to be one of Tischner's traits of thinking, which was characterized by the undertaking of a "dialogue" or even a philosophical dispute with the philosophical tradition of his epoch. During his stay in Leuven, a postdoctoral thesis entitled Phenomenology of Egotic Awareness, in which Tischner analyzed variations of primitiveness in the sphere of consciousness, and after a precise analysis of the egotistical experience and the category of the Self, as the subject of cognition in Husserl, Heidegger and Rickert proposed his own approach to the problem by introducing the concept of the "axiological self" and the associated experience of values, which will become one of Tischner's most crucial issues in the years to come [Tischner, 2006]. The very concept of the axiological self appears earlier in the essay Axiological impressions, where the irrelevance of the axiological self is clearly indicated in the Kantian approach, but also the assumption that it exists in the middle, "as an axiological positiveness, it resembles in

\footnotetext{
${ }^{1}$ See [Tischner, 2006: 412].
} 
its way of being too pure ideal values - it, just as they require realization in time and space [Tischner, 1970]. On the other hand, as something living, consensual and, above all, private, continuing to lean towards the world, where white axiological spots are located and where it can take on the robes of the social self, it makes an impression of something real,"2 so understood, the axiological self can, however, take the forms of Scheler's social self. At this point, Tischner will take up many of the views present in Scheler's thought, but by describing the axiological space, the self will clearly indicate its symbolic understanding, linked to the extra-spatial understanding of the self, following Paul Ricoeur, he will consider the symbolically captured space as "thought-provoking" and accept the hermeneutical perspective of seeking answers to the question arising in the horizon of metaphorical and symbolic meanings, which is also characteristic for Levinas' late philosophy.

After returning to Poland, he wrote the first important polemical texts on The shape of Polish dialogue [Tischner, 1979] and Christian philosophy in dialogue with Marxism [Tischner, 1979a], in which Tischner discusses the philosophical views of Marxism from an anthropological and axiological perspective. He also writes a famous article The decline of Thomistic Christianity, in which he puts forward a courageous thesis about the existence of ways to God that differ from the Thomistic one, which provokes a great discussion among Polish neo-Thomists [Tischner, 1982]. The polemical nature of Tischner's thinking leads him to adopt a twofold model of work. The first one is connected with philosophical essays, in which he interpreted hermeneutically, in a form more easily accessible to people without philosophical education, both the views of the most important thinkers of the $20^{\text {th }}$ century and the problems of a man living in a system organized according to the principles of folk democracy based on Marxist-Leninist thought. He argues both with philosophers of church circles, especially neo-Thomists, Marxist philosophers, as well as with his own masters, including Ingarden. At that time, Tischner published a great deal and became a figure without whom discussions on the shape of Marxism in Poland and Thomism could not have taken place. His writings from this period still testify to his philosophical research, whose main feature is the reference to the world of human values, but they already indicate a clear perspective of his reflections. This can be seen, for example, in the essays contained in the position The World of Human Hope, in which he points to the consequences of Marxist practice in the space of freedom, truth and hope, as well as to the ethical dimension of work [Tischner, 1992]. The polemic with Marxism has a characteristic dimension, Tischner, by taking up anthropological key issues, reveals them in their essential meaning, and such meaning refers to the meanings given to these issues in Marxist thought. However, man always remains at the centre of his attention. Here, too, there is a whole group of texts focused on the issues of freedom, values, God's experience and hope. The problem of freedom and values will continue to occupy Tischner over the next few years and will be brought about by publications such as Contemporary Philosophy and Thinking by Values [Tischner, 1989; Tischner, 1982a]. Both of these items show the spectrum of Tischner's thoughts and philosophical references, which in the years to come will determine the fundamental directions of his research. Among philosophers important to Tischner are Heidegger, Levinas, Husserl, but also Leszek Kołakowski, Franz Rosenzweig and Ricoeur, and Doctor Antoni Kępiński. Tischner not only argues with them but above all, he takes over those elements of their philosophical discourse, which he considered necessary to make his own diagnosis of human nature. During this period, the fundamental circles of his interests clearly emerge, including the phenomenology of Husserl and Heidegger, where he enters the

\footnotetext{
${ }^{2}$ See [Tischner, 1970: 215-216].
} 
space of questions about the nature of thinking, the causes of Heidegger's silence about God and fundamental ontology. The second circle is marked by studies on hermeneutical thought, its perspectives and triad: understanding-history - truth. The next circle focuses on Marxism, with which Tischner is in a dispute over a man, pointing to the problems of the Polish labour crisis and outlining the space for dialogue. The last circle is the philosophy of dialogue, rooted in the contemporary Jewish thought of Levinas and Rosenzweig, a philosophy deeply rooted in biblical tradition and introducing not only the categories of the Other but also the Infinite Traces and thinking in the perspective outlined in this way. Tischner never concealed the fact that while building his own concept of man he drew inspiration from many thinkers ${ }^{3}$. In the article What is philosophy, which I have written, ${ }^{4}$ about the crisis of human hope of contemporary man, his own search for a name to describe this crisis and the search for answers, on which he became a popularizer of the philosophy of Gabriel Marcel and other philosophers already mentioned and a thinker looking for ways to save. From this process emerged not only a specific image of a philosophical approach to human nature, a meeting or a hierarchy of values modelling our existence, but above all a structure of precise notions and issues, which Tischner referred to and used to study and diagnose the nature of the crisis of hope and philosophical search for a way out of it. At this point, the task of philosophy becomes to understand and name, and the quality of this philosophy, in his opinion, was to be determined by "the quality of human pain which philosophy wants to express and which it wants to remedy" [Tischner, 1982a: 13]. At this stage, Tischner takes over and modifies Scheller's theory of values ${ }^{5}$ in a different way than Karol Wojtyla $^{6}$ did, and at the same time introduces a hermeneutical thesis: the "symbol gives food for thought" to reflect on the relationship between symbol and existence in the perspective of what the symbolic figures from the philosophy of dialogue bring, and here he also takes up the issues of the metaphysical dimension of human existence, freedom and hope. Tischner, entering into polemics with the views of other philosophers, often ended up asking the question again, this time deepened by the sense extracted in polemics. It is becoming increasingly clear that the search for one's own concept of man will take place within the horizon of the philosophy of dialogue, and thus the philosophical description of religious thinking, metaphysical desire and separation. Tischner more and more often uses figures of thinking, which come not only from the Bible, accepted after Rosenzweig and Levinas but also from literature, as for example "people from hiding places" by Fyodor Dostoyevsky. Tischner reached the point where, asking where the philosopher's thoughts come from, he created a peculiar concept of thinking from the depths of the metaphor, which is a modern metaphor of the Platonic cave. Although the metaphor has only an auxiliary meaning, it helps in seeing and understanding, it also gives us to think, but the meta-formativity itself is already an expression of intentionality. This leads Tischner to indicate two languages in human philosophy: an unambiguous language, genrespecies language and an analogous, axiological and agathological language, which is at the same time a symbolic language. Defending the law of the philosophical powers of metaphorics, Tischner pointed to a form of thinking which "transforms into criticism of the direct world for the fact that it creates in us the illusion of the real world" [Wojtyła, 1991: 480]. Thus, everything that was necessary to create one's own concept has already been done, and the effect of the following years of work was the writing of two most important books: Philosophy of Drama and Dispute Over the Existence of Man [Tischner, 1990; Tischner, 1998].

\footnotetext{
${ }^{3}$ Compare, [Tischner, 1982a: 17-201].

${ }^{4}$ Compare, [Tischner, 1982a: 9-13].

${ }^{5}$ See [Tischner, 1984].

${ }^{6}$ See [Wojtyła, 1991].
} 
In the Philosophy of Drama, the concept of man as a dramatic being appears. The drama of man begins with the meeting of another man; there is a source experience that is different from the experience of the world - the scene. As a result of the encounter, not only the consciousness of the other person appears but also the Trace of the Infinite. Tischner introduces the figure of the drama as a model for describing the existence of man in the world of interpersonal relations based on freedom and values. The drama of the human condition manifests itself in its being against values. The human subject, unable to exist beyond values, inscribes his existence in a continuous process of their preferences, that is, choosing. The meeting of the other man, at the same time, opening the horizon of the values at the same time and activates the procedure of preferences. This dramatic happening has two important aspects. The first is horizontality, and the second is a tragedy.

In the first case, Tischner, following the findings of Otto Friedrich Bollnow, ${ }^{7}$ introduces an irrevocable category of the horizon defining the world of the human environment. Thanks to this, he constructs the concept of the horizon of the meeting and the category of out-of-scene space connected with this concept. This category remains in opposition to the concept of stage space. At the same time, for Tischner stage space is empirically a given space, in which beings functioning within it exist, according to the rule, one next to the other. It is in this space that man finds himself next to things and faces the other person. However, the specificity of the meeting is also determined by the out-of-scene space, which for Tischner has the character of a discontinuous space of meaning and it is in this space that the world of values should be searched for. Thus, Tischner introduces to his philosophy not only concepts which have all the features of aesthetic thinking, but also in radically changed meanings, but also describes the mechanism of introducing values into the interpersonal world by man, in a way per se. As a result, man, as a persona, becomes in Tischner's thought the subject of values and his nature is determined by his axiological choices and the values he introduces into the world. Making the world interpersonally valuable, a man also defines himself through the values he introduces into the world. In Tischner's writings, we find two basic types of horizons, the first of which is the agathological horizon, set in the metaphysical reflection characteristic of religious thinking. In the field of this horizon, man can raise or lose his humanity, while the second horizon, the axiological horizon within which man chooses values, is the horizon of searching for ways of salvation. At this point, it should be mentioned that Tischner did not practice metaphysical reflection in this model like neo-Tomism. However, he did not flee from fundamental problems, such as evil, by introducing in their description not only the symbolic thinking characteristic of Ricoeur but also the horizon of meanings founding human choices and at the same time escaping human reflection. It seems that in this aspect he followed the path set by the French philosopher Maurice Nedoncelle.

Tragism, as the second and important aspect of man's dramatic existence, is a consequence of man's choices and the ability to read the meanings that occur on the stage of interpersonal relations. For this reason, Tischner will argue that the philosophy of drama is a philosophy of customs, that is, the proper revealing of the content that we encounter in a meeting with another human being. The essence of tragic existence is entanglement in evil, which according to Tischner is an illusion of existence. Thus, by choosing evil and introducing it into the world of human relations, the subject is placed on the side of ontical illusion, which results in a fall. Getting entangled in the illusion of evil is tantamount to the loss of freedom. Tischner describes the mechanism of such entanglement very precisely. At the same time, he clearly

\footnotetext{
${ }^{7}$ See [Bollnow, 2010].
} 
emphasizes that such a decision is always based on human freedom, which funds the moment in which man says "yes" to what evil brings with it. However, while the rule itself is the only rule based on the source experience of freedom, the mechanism itself gets caught up in evil is based on a whole paradigm of different attitudes. Looking for reasons why the man says "yes" to evil, Tischner does not reach for metaphysical categories. On the contrary, it points to the most empirical aspects of human existence, such as fear, lies, pride and suffering. According to Tischner, all these aspects of human existence appear in the dialogue space and lead to the enslavement of man. Hence the existence of man, who succumbs to evil, he describes as a tragic existence. However, as a philosopher of human hope, Tischner did not exclude a situation in which man can free himself from the influence of evil and begin to experience his own freedom anew. He called this type of existence - "heroic existence"

The category of the meeting is fundamental in this case, whether reciprocity or refusal will affect each of the participants of the meeting and the world in which the meeting takes place. In fact, a person can only achieve the fullness of his or her humanity in the field of the meeting. It is in it that man finds not only his own freedom, thanks to which he makes axiological choices, but also manifests himself to others looking for his place in the world and the sense of his own existence. Facing the other, Tischner takes an attitude different from being in the world of things, and at the same time, to describe his presence in relation to the other, Tischner introduces the concepts of Faces, Masks and Curtains. He refers at this point to the figures that Levinas had already used. Levinas claimed that man manifesting himself to others in all his nature and human poverty does it through his face. For this reason, Levinas claimed that man is even a Face. For Tischner, a manifestation to the other in the form of the Face is the manifestation of man in all his truth. Only such a manifestation can result in a fullfledged meeting. It also creates a personal horizon of meaning, which defines the subjective possibilities of each participant of the meeting. The other two figures are used to describe dysfunctions within a meeting. The veil tries to close the Second One's access to the Self, while the Mask introduces falsehood into the horizon of interpersonal relations and as such defines a manifestation excluding the meeting with all the consequences for both participants of this event. The whole dramatic meeting takes place in the axiological and agatological horizon. The first is a space of searching for ways to save, the second is to take up or lose humanity. Values introduced by man into the world of interpersonal relations also define his nature. While drama is the ability of a person to accept good or evil, tragedy is a fall into evil, while heroism is a rise from evil. He introduces a dialogical concept of evil and a model of wandering in the elements of beauty, truth and goodness. He describes precisely the mechanisms involved in evil in the dialogue area, as well as the consequences of the encounter for the image of the human world, which is closed in four symbolic places: a house, a workshop, a temple and a cemetery, which in case of refusal become a hiding place, a place of drudgery, an empty temple and an anonymous bottom.

Analyses of the effects of the meeting conducted by Tischner had at least several dimensions. The first one referred to Tischner's polemical attitude to the Heidegger concept of Dasein. Describing human subjectivity from the perspective of independent human being, as Dasein remains, was in conflict with Tischner's dialogical approach. At the same time, Tischner's dialogicality also has several dimensions. He inscribes it both in the process of searching by the Self for the sense of one's own existence, the main determinant of which is to find a community living according to the same ethos. Thus, dialogue introduces both interpersonal relations on the plane of co-existence and axiology. These planes permeate each other and 
lead to the manifestation of human freedom appearing in the field of choice of values as well as their active introduction into the world of human relations. Here appears an extremely important aspect of the dialogical nature of man, it concerns the understanding of the nature of the world around him and the accurate reading of the content that other people bring into this world. The first aspect is important for Tischner as he introduces categories of wandering in several axiological elements such as goodness, beauty or truth. Thus, entering the stage of a drama, a human being faces a whole range of senses that are somehow inflicted on him. To a large extent, his whole existence will depend on their correct understanding. The nature of wandering is that the human subject has an epistemological problem. This is to a large extent explained in this philosophy by the entanglement in evil or other forms of enslavement. One can be enslaved by beauty, confuse it with good and make it the most fundamental value. Freedom is then lost in favour of enslavement through beauty, the presence of which in the environment of man becomes a sine qua non of his harmonious, though enslaved existence. In this aspect, beauty reveals its tragic dimension. Wandering in the element of goodness reduces Tischner to an in-depth analysis of lies. Here he introduces the category of double dialogue. On the first level, the dialogue takes place between the lying Self and the ideal You, to whom the true message is revealed. This procedure is necessary for the existence of the second level, which already takes place in the real dimension of the meeting, when the Self, knowing the truth that you "communicated" at the ideal level, now surrenders it to the operation of misrepresentation. This results above all in a state of affairs in which you are denied the right to truth in a dialogical relationship, thus destroying the very nature of the encounter. A classic example of such an event is being towards a man who manifests himself on stage in the form of a Mask. The third type of wandering is the wandering in the element of good, in which Tischner analyses the mechanisms of dialogical evil, which man, with his own approval, introduces into the world of interpersonal relations. Tischner described not only the mechanisms of decline, which give rise to a crisis of hope but also the mechanisms of cognition error, which was at the root of the Marxist utopia. In his philosophy, man is not an anonymous element of political statistics, but a person who seeks radical meaning in meeting others, follows the Traces of Transcendence, takes up the call of those who have already left this world and, above all, there is a dramatic tension of good and evil, in which he wanders, wants to think from the depths of the metaphor and seeks another, in meeting with which he discovers or loses the sense of his own existence. The nature of a meeting is not only to enter the axiological horizon in which the other meets or is denied. The most important consequence of the meeting is not only a conscious attitude towards human poverty, which Tischner symbolically evokes in the figures of an orphan, a foreigner and a widow in the Bible but above all a conscious and practical undertaking of help in response to a call for help from the other. The most important moment here is Tischner's pointing out that the master of questions (allowing for an accurate revealing of the nature of the dialogue world) is precisely the subject of human poverty. And it is he who ultimately is the man who, by becoming the subject of his misery and carrying it in a situation where he is already helpless to achieve the fullness of his own humanity. Of course, the encounter that leads to the emergence of a community living according to one commonly accepted ethos leads to a transformation of the world of human presence. However, the nature of this world, which is the fruit of the encounter, is complicated. A house that is the reciprocity between man and woman is a place whose nature defines desolation. We are in it for a short time and we leave the rest of the population without the opportunity to meet with us. A work workshop, so important in Marxist thought, is a place where the nature of the world is transformed into 
a subjective one. The work that man does in it is not only to ennoble it but also above all to make its existence meaningful and fulfilled. The temple in which man enters the agatological horizon is not a place of meeting, which is a consequence of God's hiding in transcendence but is a place of sanctification. The most mysterious place, however, remains the cemetery, where the meeting has a dimension of taking up ethos, those who before us constituted places in which we now live among people whom we consider to be our own community. Of course, if in the case of a meeting a person creates places of community, and then as a result of a refusal to meet there will be places of refusal. The house will become a hiding place where people from the hiding place created by Fyodor Dostoyevsky will be living by Tischner's calls. For them, the world is no longer hopeless and they, in secret, consider this state of their own existence to be unchangeable. The labor workshop will become the penitentiary and forced labor camp in which labor is to kill. The temple will be deserted and ruined, and the deceased will be denied the right to the cemetery so that no one can take up their ethos anymore. The most painful analyses are those in which Tischner addresses the issues of betrayal but also deafening pain. They are connected with two attitudes towards the consequences of dialogical evil. The first one leads to sacrifice and the second to betrayal.

Tischner's recent works have a very broad perspective. For several years he has been creating Philosophy in Highlander Style, in which, based on the example of Highlander wisdom, he often points to its convergence with classical philosophical thought [Tischner, 1997]. Another position is, as it were, the opus magnum, i.e. the Dispute over the Existence of Man, which was intended to be a response to a dispute in this matter that he had with Roman Ingarden, which lasted for years [Tischner, 1998]. The last item written during the course of the deadly disease is the Priest on Astray [Tischner, 1999].

After Tischner's death, the research on his legacy was taken over by the Józef Tischner Thoughts Institute, which together with the Vienna Institute of Human Sciences (which he cocreated together with Hans-Georg Gadamer) and Kraków's universities organises the annual Tischner Days in Kraków. After many years of hard work, Tischner's students began to publish a full version of his writings containing not only the most important scientific dissertations, previously published for obvious reasons in a small print run but also lectures, which always filled the biggest halls and have already passed to the university's legend.

\section{References}

Bollnow, Otto Friedrich. Mensch und Raum. Kohlhammer W., 2010.

Tischner, Józef. Axiological impressions. Znak, 1970.

Tischner, Józef. The shape of Polish dialogue. Kraków, 1979.

Tischner, Józef. Christian philosophy in dialogue with Marxism. Kraków, 1979a.

Tischner, Józef. The decline of Thomistic Christianity. [in:] the same, Thinking by values. Kraków, 1982: 205-228.

Tischner, Józef. Thinking by Values. Kraków, 1982a.

Tischner, Józef. Ethics of the value of hope, [in:] D. von Hildebrand, J.A. Kłoczowski, J. Paściak, J. Tischner. In terms of value. Poznań, 1984: 55-153.

Tischner, Józef. Contemporary Philosophy. Kraków, 1989.

Tischner, Józef. Philosophy of Drama. Paris, 1990.

Tischner, Józef. The world of Human Hope. Choice of philosophical sketches 1966-1975. Kraków, 1992. 
Tischner, Józef. Philosophy in Highlander Style. Kraków, 1997.

Tischner, Józef. Dispute Over the Existence of Man. Kraków, 1998.

Tischner, Józef. Priest on Astray. Kraków, 1999.

Tischner, Józef. The Transcendent Self in the Philosophy of Edmund Husserl. [in:] the same, Collected Works. Studies in the philosophy of consciousness, scientific research A. Wegrzecki. Kraków, 2006: 3-123.

Tischner, Józef. Phenomenology of Egotic Awareness. [in:] the same, Collected Works. Studies in the philosophy of consciousness, scientific research A. Wegrzecki. Kraków, 2006: 131-311.

Wojtyla, Karol. Issues of the Subject of Morality. Lublin, 1991. 